Original Paper http://ajol.info/index.php/ijbcs http://indexmedicus.afro.who.int

\title{
Morphotaxonomy and histopathology of three species of Myxobolus Bütschli, 1882 parasites of Enteromius martorelli Roman, 1971 from the Anga River in Cameroon
}

\author{
Guy Benoît LEKEUFACK FOLEFACK ${ }^{1 *}$, Amandine Estelle TCHOUTEZO TIWA ${ }^{1}$, \\ Bienvenu FEUDJIO DONGMO ${ }^{1}$, Lohik MBOLANG NGUEGANG ${ }^{2}$ and \\ Abraham FOMENA ${ }^{1}$ \\ ${ }^{1}$ Laboratory of Parasitology and Ecology, Department of Animal Biology and Physiology, Faculty of Sciences, \\ University of Yaounde I, Po. Box: 812 Yaounde, Cameroon. \\ ${ }^{2}$ Laboratory of animal Physiology, Department of Animal Biology and Physiology, Faculty of Sciences, \\ University of Yaounde I, Po. Box: 812 Yaounde, Cameroon. \\ *Corresponding author, E-mail: leguyzo@yahoo.fr; Tel: 00237677887294
}

\begin{abstract}
Myxosporea are almost exclusively fish parasites and have been recognized as a key limiting factor in the development of aquaculture. For this, we aimed at studying myxosporean, parasites of Enteromius martorelli so as to facilitate their future comparative identification and provide histopathological data. The morphological and metric characteristics of myxospores harvested fit together with those of Myxobolus nyongana; Myxobolus oloi and Myxobolus njinei. Histological funding revealed that $M$ nyongana form plasmodia in the lumen of vascular network directly at the base of the secondary gill lamellae and result in deformation of adjacent gill lamellae. Plasmodia of $M$. olo $i$ were implanted between the muscle fibers and exert a mechanical pressure on the adjacent cells. M. njinei affected the fins and gill. Plasmodia of $M$. njinei on fins occur in three typical locations: between the finrays; inside the lumen of the finrays; and the outer surface of the hemisegments under the basal lamina. Parasites species harvested exhibited two type of specificity: euryxenous and mesostenoxenous. Given the lack of knowledge on pathogens that affect E. martorelli, data from the present study could be of considerable importance in the handling of the species under cultivation.

(C) 2019 International Formulae Group. All rights reserved
\end{abstract}

Keywords: Myxobolus nyongana; Myxobolus oloi; Myxobolus njinei; Cyprinid fish

\section{INTRODUCTION}

Fish species of the genus Enteromius Cope, 1867 (Syn: Barbus Cuvier and Cloquet, 1816) (Hayes and Armbruster, 2017), due to their number, adaptation to all environment and easy breeding play an important role in human nutrition and international trade as aquarium fish (Lipato and Kapute, 2017).
However, these fish also constitute a favourable biotope for the development of a large number of parasites, including Myxosporidia (Lekeufack et al., 2017).

Myxosporidia are among the most important fish parasites (Lom and Dyková, 2006), with about 2200 currently known species (Fiala et al., 2015). These parasites 
mainly infect fish, but some have been recorded on Trematoda, Crustaceans, Amphibians, Reptiles, Birds and Mammals (Lom and Dyková, 2006). Among Myxosporidia, species of the genus Myxobolus Bütschli, 1882 are so far the most commonly found in fish, with approximately 905 known species all over the world (Eiras et al., 2005, 2014). Myxobolus species infect numerous fish organs and are responsible of a wide variety of damages (Lom and Dyková, 2006; Lekeufack Folefack and Fomena, 2013). The extent of damage to organs and tissues depend on the parasite species, its life cycle, infection intensity, and host response (Lom and Dyková, 2006). Histozoic species of myxosporidia parasitizing fish is well documented and attention has been focussed mainly on the description of myxospores. There are few studies on histopathological changes caused by myxosporidia on African freshwater fishes. Recent studies have suggested that host and organ specificity and also tissue tropism should be taken into consideration in myxosporidia species identification (Molnár, 2002a, 2002b, 2007).

The number of myxosporidia described from fish species of the genus Enteromius include about forty (40) Myxobolus species (Lekeufack et al., 2017). Some of these parasite species have been described without complete data on vegetative stages.

The present paper is part of an ongoing investigation into the characteristics of myxosporidia parasites of freshwater fish in Cameroon, with the aim to supplement morphological and metric characteristics of Myxobolus nyongana (Fomena, Bouix and Birgi, 1985) Fomena and Bouix, 1997, Myxobolus oloi Fomena and Bouix, 1994 and Myxobolus njinei Fomena, Birgi and Bouix, 1985 with histopathological data so as to facilitate their future comparative identification.

\section{MATERIALS AND METHODS}

Data on host fish and study site

Enteromius martorelli Roman, 1971

(Syn: Barbus martorelli) (Hayes and Armbruster, 2017) is a Cyprinid fish widely distributed in rivers and streams in West and Central Africa. This gregarious and omnivorous fish can easily adapt to aquatic environment changes, and can be found in both lotic and lentic habitats. Furthermore, this fish species has a commercial value in natural and man-made lakes due to its delicious flesh (Lipato and Kapute, 2017). Forty eight (48) specimens of E. martorelli with standard length varying between 35 and $90 \mathrm{~mm}$ were harvested from March to July 2017 in river Anga (a sub tributary of the river Nyong) at Ongot, a small village of the district of Mbankomo (Department of Mefou and Akono, Central Region). This village is elevated at $720 \mathrm{~m}$, between $3^{\circ} 31^{\prime}$ and $4^{\circ}$ north latitude and $11^{\circ} 13^{\prime}$, and $12^{\circ}$ longitude east. The climate is the equatorial transition type in this locality, is characterized by two rainy seasons (September to mid-November and mid-March to June) and two dry seasons (mid-November to mid-March and July to August) of unequal importance. The mean annual rainfall is $1645 \mathrm{~mm}$. The primitive vegetation is the rainforest or hemiombrophilous forest.

\section{Fishing and fish conservation}

Fish capture was carried out using the fishing rod. In the field, once the fish were caught, a buttonhole was made on the abdominal region of each host individual. The latter were immediately immersed in a $10 \%$ solution of formalin. Systematic position of sampled fishes was taken from Stiassny et al. (2007).

\section{Fish dissection and parasites collection}

In the laboratory, fish were first examined with the naked eye (eyes, fins, operculum, scales, skin) and then with the 
Olympus BO61 stereoscopic microscope, to detect the presence of cysts. After dissection of the hosts, internal organs (gills, heart, liver, kidneys, spleen, gallbladder, gonads, intestine and urethra) were taken individually and examined. Cyst content was identified with the objective 100X of an YVYMEN optical microscope. The content of the gallbladder was examined between slide and cover glass under the microscope. The smears of the kidney, spleen, liver, gonads, heart and urethra were mounted on slides and examined at the $40 \mathrm{X}$ objective of the microscope.

\section{Histopathological study}

Small fragments of affected gills, muscles and fins were carefully removed from parasitized host fish and placed in a 10\% formalin solution. These affected tissues were post fixed in Bouin's solution for more than 2 hours. Dehydration of tissues was done by immersing the tissues into a series of baths containing ethanol of increasing concentration (a bath in 70\%, 2 baths in $95 \%$ and 3 baths in $100 \%)$. Dehydrated affected tissues were then cleared in 2 baths of xylene solution. The tissues were embedded in molten paraffin wax at about $52{ }^{\circ} \mathrm{C}$ and thin sections (5 to $8 \mu \mathrm{m}$ ) of tissue samples were obtained using Manual Rotary Reichert-Jung 2030 microtome. The sections obtained were immersed in a hot gelatinized water bath at $40{ }^{\circ} \mathrm{C}$, then spread on a glass slide and dried in an oven (24 hours at $45^{\circ} \mathrm{C}$ ) to be coloured.

\section{Stainning, photography and spores measurement}

Spore smears were fixed with methanol and stained with May-Grünwald-Giemsa. Tissue sections were stained with haematoxylin and eosin (H\&E). Haematoxylin was the nuclear stain while eosin was the cytoplasmic stain. The stained histopathological slides were studied under optical microscope. The photographs of parasitized organs were done using a Nikon
COOLPIX S2800 digital camera. Those of the myxospores and tissue sections were done using an Olympus BH-2 optical microscope equipped with a microphotography device. Measurements were carried out on a sample of 50 fresh myxospores using an objective micrometer. The selected variables are those proposed by Lom and Arthur (1989). The data obtained after measurement are rendered in the form $\bar{x}$ (Xmin - Xmax). In this form, $\bar{x}$ is the arithmetic mean of the studied variable, $\mathrm{Xmin}$ is the observed minimal value and $\mathrm{Xmax}$ represented the maximum value observed.

\section{RESULTS}

Myxobolus nyongana (Fomena, Bouix and Birgi, 1985) Fomena and Bouix, 1997

Affected organ: Gill.

Prevalence: $50 \%$ (24 parasitized fish out of 48 sampled).

Vegetative form: The parasite forms whitish cysts which are incrusted between the secondary gill lamellae (Figures 1a,b). These polysporous cysts are ovoid or spherical. They were not uniform in size and measured 60 $290 \mu \mathrm{m}$ long $\mathrm{x} 75-265 \mu \mathrm{m}$ wide. Per parasitized fish host, up to 75 cysts can be counted.

Histopathology: Histopathological findings indicate that the cyst of $M$. nyongana are located in the lumen of vascular network directly at the base of the secondary gill lamellae and result in deformation of adjacent gill lamellae (Figures 1a,b). There is destruction of the engulfed gill lamellae after bursting of the cyst (Figure 1c). After maturation of the cysts, spores are often released into the water by rupture of the wall (Figure 1c).

Spore: Spores are ovoid with tapered anterior end, the posterior end being broad and rounded (Figure 1d). Polar capsules are pyriform and equal (Figures 1d,e). The polar filament coils are arranged perpendicularly to the long axis of the capsule. The sporoplasm 
often contains an iodinophilous vacuole (Figure 1d).

Measurements: Spore measurements are given in Table 1.

\section{Myxobolus oloi Fomena and Bouix, 1994}

Affected organs: Muscle, kidneys, spleen and gonads.

Prevalence: $20.83 \%$ (10 parasitized fish out of 48 sampled).

Vegetative form: Incrusted between muscular fibers (Figure 2a), cysts are whitish, elongated and polysporous. They measure 160 - $300 \mu \mathrm{m}$ long x 100 - $115 \mu \mathrm{m}$ wide. In spleen, kidneys and gonads, only diffuse spores were found.

Histopathology: Plasmodia of $M$. oloi are implanted between the muscle fibers of the host. It contains a high number of spores in various developmental stages and exerts mechanical compression on the adjacent cells (Arrows) (Figure 2a).

Spore: spores are ovoid with rounded ends. There is no intercapsular appendix. Polar capsules are pyriform and unnequal (Figures 2b,c). The larger polar capsule contains 6 to 7 polar filament coils while the smaller contains 4 to 5 . The sporoplasm is finely granular (Figure 2b).

Measurements: Spore measurements are given in Table 2 .

\section{Myxobolus njinei Fomena, Birgi and Bouix, 1985}

Affected organs: Fin and gill.

Prevalence: $47.92 \%$ (23 parasitized fish out of 48 sampled).

Vegetative form: Whitish, ovoid and polysporous cysts were found on the gill arch and fins. In the fins (Figures 3a,b), cysts are located in the finrays, between the finrays and contiguous to the finrays (Figure 3b). They measure $160 \mu \mathrm{m}-1.5 \mathrm{~mm}$ long x $130-650$ $\mu \mathrm{m}$ wide. An individual fish host can carry up to 50 cysts.
Histopathology: Plasmodia were located mostly in the tail fin. Infections of fins occur in three typical locations (Figure 3b). In the first case, plasmodia were located in the loose connective tissue layer of the skin doublets between the finrays (Figure 3c). They were surrounded by a thin layer of connective tissue cells deriving from the capillary rich connective tissue which underline the epithelium of the fin. Secondly, cysts were located inside the lumen of the 2 hemisegments constituting the cartilaginous finrays. Some cysts bulges from the intrasegmental region into the interlepidotrichial space (arrow) (Figure 3d). The wall of the plasmodium was composed of two layers (Figure 3e). The inner layer (arrow) was of parasite origin and consisted of the thin eosinophilic ectoplasm of the plasmodium. The external layer (arrowheads), however, seemed to be of host origin and composed of a cartilaginous capsule formed by acellular bundles of collagen fibres associated with the surrounding connective tissue which form the cartilage of the hemisegments of the finrays (Figure 3e). In the third case, plasmodia were found attached to the outer surface of the hemisegments under the basal lamina (Figure 3f). No morphological changes were found in the connective tissue and cartilaginous structure of the hemisegments and no inflammatory reaction was recorded. The cysts were not uniform in size suggesting an asynchronous infection and cysts development.

Spores: Spores are subspherical with truncated anterior end. At the anterior end, there is a well-developed intercapsular process measuring 3.1 (2.8 - 3.8) $\mu \mathrm{m}$ long (Figure 4a). Polar capsules are piriform and equal (Figures $4 a, b)$. In each of them, 6 to 8 coils of the filament are counted. The sporoplasm often contains an iodinophilous vacuole (Figure 4a).

Measurements: Spore measurements are given in Table 3 . 



Figure 1(a-d): Optical photomicrographs of plasmodia and myxospores of Myxobolus nyongana parasitizing secondary gill lamellae of Enteromius martorelli. a. Young cysts; b. Deformation of secondary gill lamellae adjacent to the plasmodium (P); c. Destruction of secondary gill lamellae; d. Fresh myxospores e. stained myxospores. 

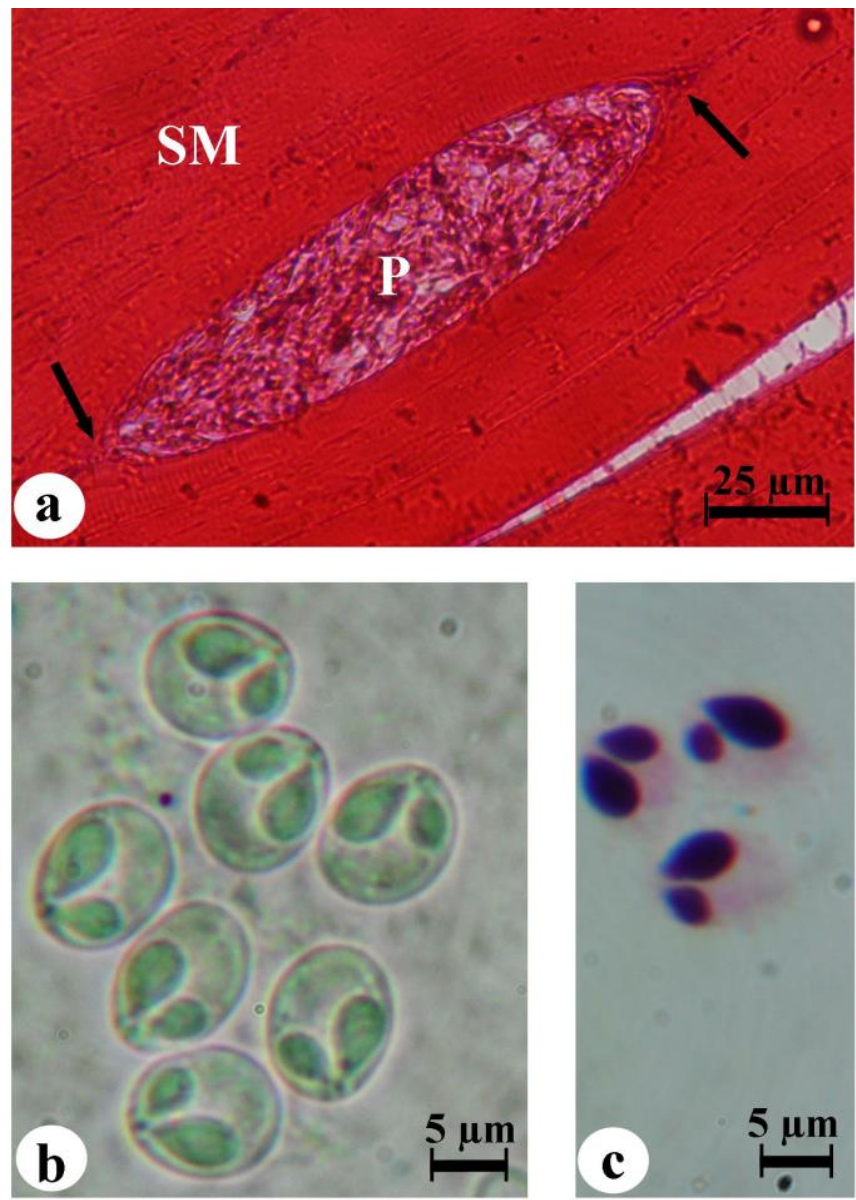

Figure 2(a-c): Optical photomicrographs of plasmodium and myxospores of Myxobolus oloi parasitizing skeletal muscle (SM) of Enteromius martorelli. a. Plasmodium (P); b. Fresh myxospores; c. Coloured myxospores.

\section{DISCUSSION}

Based on the morphological and metric characteristics of the myxospores, species of myxosporidia studied in the present work were identified as Myxobolus nyongana (Fomena, Bouix and Birgi, 1985) Fomena and Bouix, 1997; Myxobolus oloi Fomena and Bouix, 1994 and Myxobolus njinei Fomena, Birgi and Bouix, 1985. Out of 2200 known species of myxosporidia (Fiala et al., 2015), the genus Myxobolus with approximately 905 species is numerically the largest group (Eiras et al., 2005, 2014). Myxobolus species are usually histozoic in freshwater fish and form at maturity cysts in tissues or organs (Lom and Dyková, 2006). Moreover, it seems probable that the majority of Myxosporidia species can develop only in fish species most closely related to their type host (Molnár and Eszterbauer, 2015).

Originally described in Cyprinids fish of the genus Enteromius (syn: Barbus) (E. aspilus, E. camptacanthus, E. marterolli, E. jae, E. guirali) in Cameroon (Fomena et al., 1985), the presence of $M$. nyongana in one of its original hosts species (E. martorelli) was recorded in the present study. Despite this observation, $M$. nyongana was reported in: Sarotherodon melanotheron (Cichlidae) in Benin (Sakiti et al., 1991); 

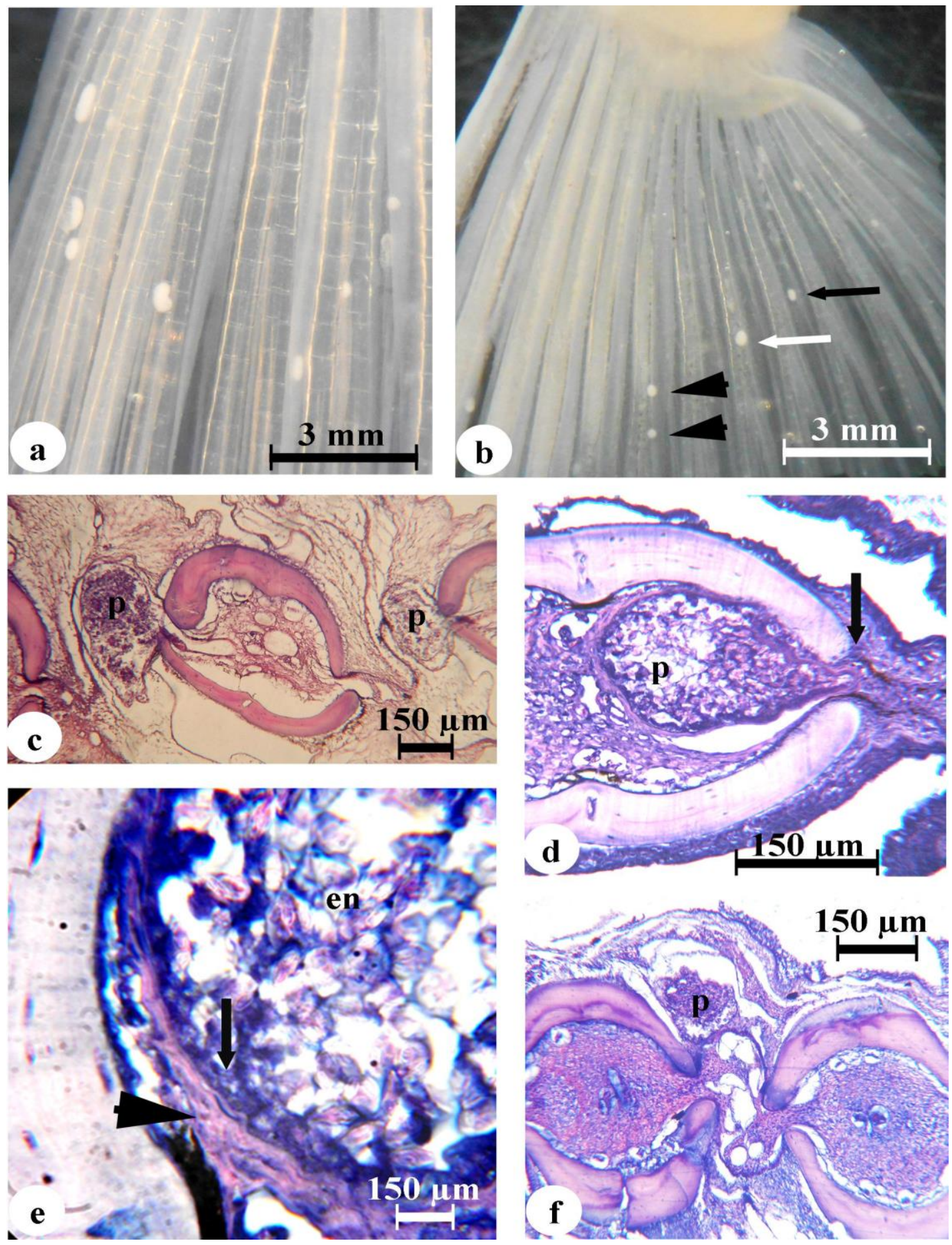

Figure 3(a-f): Optical photomicrographs of cysts of Myxobolus njinei parasitizing fins of Enteromius martorelli. a. Plasmodia implanted on fin. b. Fin showing plasmodia with three different location: located between the finrays (black arrow), located in finrays (white arrow) and contiguous to the finrays (arrowheads). c. Plasmodia (p) developing in the interlepidotrichial region. d. Plasmodium (p) in the lumen of one of the finray. e. Part of a plasmodium showing endoplasm (en) and cell wall made of inner layer (arrow) and external layer (arrowheads). f. Plasmodium (p) developing on the outer surface of the finrays. 


\section{G. B. LEKEUFACK FOLEFACK et al. / Int. J. Biol. Chem. Sci. 13(3): 1705-1719, 2019}

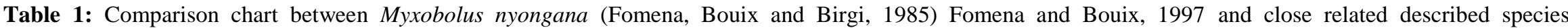
(measurements in micrometers)

\begin{tabular}{|c|c|c|c|c|c|c|c|c|c|c|}
\hline Parasite species & Host species & Infestation site & Country & SL & SW & PC & LPC & WPC & PF & ICA \\
\hline M. amieti Fomena et al., 1985 & Ctenopoma nanum & spleen, eye & Cameroon & $4.0(11.3-15.8)$ & $7.4(5.4-8.7)$ & $=$ & $8.4(6.0-10.0)$ & $1.9(1.4-2.5$ & I & $\mathrm{A}$ \\
\hline M. beninensis Sakiti et al., 1991 & $\begin{array}{l}\text { Saratherodon } \\
\text { melanotheron }\end{array}$ & $\begin{array}{l}\text { gill arch connective } \\
\text { tissue }\end{array}$ & Benin & $2.5(10.5-14)$ & $7.2(5.5-9)$ & $=$ & $6.9(6-8)$ & $2.2(1.5-3)$ & $8-10$ & A \\
\hline $\begin{array}{l}\text { M. chinsurahensis Basu and Haldar, } \\
2003\end{array}$ & Anabas testudineus & scales & India & $8.4(8.0-9.7)$ & $5.4(5.1-6.1)$ & $=$ & $4.4(3.9-6.6)$ & $2.1(1.8-2.5)$ & $5-6$ & $\mathrm{P}$ \\
\hline M. dahomeyensis Siau, 1971 & Synodontis ansorgii & ovary & Dahomey & 12 & 6 & $=$ & $4-5$ & I & I & A \\
\hline M. eucalii Guilford, 1965 & Eucalia inconstans & $\begin{array}{l}\text { cranium, } \\
\text { pectoral fins }\end{array}$ & USA & $14.4(12.0-15.6)$ & $9.9(8.4-10.8)$ & $=$ & $11.1(9.6-12.0)$ & $3.7(3.0-4.8)$ & $9-11$ & A \\
\hline M. heterosporus Baker, 1963 & Tilapia esculenta & viscera & Uganda & $12.5(8.5-17.0)$ & $8.3(6.5-11)$ & $=$ & $4.1(2.0-5.5)$ & $2.3(1.5-3.5)$ & I & A \\
\hline M. israelensis Landsberg, 1985 & Sarotherodon galilaeus & kidneys, spleen & Israël & $12.5(11.4-13.9)$ & $8.8(7.6-9.7)$ & $=$ & $7.7(7.0-8.2)$ & $3.5(3.2-4.0)$ & $7-8$ & A \\
\hline M. koi Kudo, 1919 & Cyprinus carpio & gills & Japan & $14-16$ & $8-9$ & $=$ & $8-9$ & $2.5-3$ & I & A \\
\hline M. kribiensis Fomena and Bouix, 1994 & Brycinus longispinnis & skin, eye sclera & Cameroon & $21.2(20.2-23.0)$ & $9.5(9.0-10.0)$ & $=, \neq$ & $16.1(14.5-17.6)$ & $15.4(13.5-16.9)$ & $19-28$ & A \\
\hline M. macrocapsularis Reuss, 1906 & Blicca bjoerkna & gills & Russia & $9-14.5$ & $6-9.9$ & $=$ & $5-8.6$ & $2.4-3.6$ & I & A \\
\hline M. nyongana Fomena and Bouix, 1997 & $\begin{array}{l}\text { Enteromius aspilus } \\
\text { E. camptacanthus } \\
\text { E. guirali } \\
\text { E. jae } \\
\text { E. martoreli }\end{array}$ & gills & Cameroon & $10.8(7.3-13.0)$ & $6.0(5.0-7.0)$ & $=$ & $5.9(5.0-7.0)$ & $1.9(1.4-2.5)$ & 6-9 & $\mathbf{A}$ \\
\hline M. nyongana (Present study) & E. martorelli & gills & Cameroon & $9.0(8-10)$ & $5.9(5-6.3)$ & $=$ & $4.3(3.8-5.1)$ & $1.9(1.5-2.3)$ & 6-7 & $\mathbf{A}$ \\
\hline M. paludinosus Reed et al., 2002 & $\begin{array}{l}\text { Enteromius } \\
\text { paludinosus }\end{array}$ & gills & Botswana & $12.0(11.2-13.7)$ & $8.6(7.5-10.0)$ & $=$ & $5.7(5.0-6.8)$ & $2.4(2.0-2.5)$ & $6-7$ & A \\
\hline M. sangei Fomena et al., 2007 & $\begin{array}{l}\text { Brycinus } \\
\text { macrolepidotus }\end{array}$ & gills, skin, kidney & Cameroon & $9-10.5(10.1)$ & $6.0-6.9(6.2)$ & $\neq$ & $\begin{array}{l}5.7-7.0(6.2)^{*} \\
4.0-5.5(4.8)^{* *}\end{array}$ & $\begin{array}{l}2.0-3.0(2.2)^{*} \\
1.5-2.0(1.7)^{* *}\end{array}$ & $\begin{array}{l}7-8^{*} \\
4-5^{* *}\end{array}$ & A \\
\hline M. zillii Sakiti et al., 1991 & Tilapia zillii & gills & Benin & $9.8(8-11)$ & $7.5(6-8)$ & $=$ & $5.1(4-6)$ & $2.5(2-3)$ & & $\mathrm{A}$ \\
\hline
\end{tabular}

The arithmetic means of the measured variables are followed in brackets by the minimum and maximum values

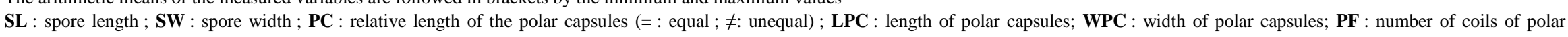
filament; ICA : intercapsular appendix (A : absent ; P : present) ; * Relative to the large polar capsule; ** : Relative to the small polar capsule;

/: No data available. 
G. B. LEKEUFACK FOLEFACK et al. / Int. J. Biol. Chem. Sci. 13(3): 1705-1719, 2019

Table 2: Comparison chart between Myxobolus oloi Fomena and Bouix, 1994 and close related described species (measurements in micrometers).

\begin{tabular}{|c|c|c|c|c|c|c|c|c|c|c|}
\hline Parasite species & Host species & Infestation site & Country & SL & SW & PC & LPC & WPC & PF & ICA \\
\hline $\begin{array}{l}\text { M. bhadrensis Seenappa and } \\
\text { Manohar, } 1981\end{array}$ & Labeo rohita & muscle & India & $9.5(8.0-11.0)$ & $7.1(7.0-8.0)$ & $\neq$ & $\begin{array}{l}3.5(3.0-4.0)^{*} \\
2.5(2.0-4.0)^{* *}\end{array}$ & $\begin{array}{l}2.2(2.0-3.0)^{*} \\
1.75(1.0-2.0)^{* *}\end{array}$ & I & A \\
\hline $\begin{array}{l}\text { Myxobolus bilongi Fomena et al., } \\
1994\end{array}$ & Labeo sp. & gills, fins & Cameroon & $15.3(14-17)$ & $12.2(11.3-14.5)$ & $\neq$ & $\begin{array}{l}7.4(6.5-8)^{*} \\
5.3(4.1-6.5)^{* *}\end{array}$ & $\begin{array}{l}4.8(4-6) * \\
3.5(3-4) * *\end{array}$ & $\begin{array}{l}9-10^{*} \\
6-7 * *\end{array}$ & $\mathrm{P}$ \\
\hline M. burkinei Kabré et al., 1995 & Labeo coubie & fins & Burkina Faso & 12.2 & 9.3 & $\neq$ & $\begin{array}{l}6.1^{*} \\
4.0^{* *}\end{array}$ & $\begin{array}{l}3.5^{*} \\
2.2 * *\end{array}$ & $\begin{array}{l}5^{*} \\
3^{* *}\end{array}$ & $\mathrm{P}$ \\
\hline M. dossoui Sakiti et al., 1991 & $\begin{array}{l}\text { Tilapia zilli; } \\
\text { Hemichromis fasciatus; } \\
\text { Tilapia hybrid }\end{array}$ & gill arches cartilage & Benin & $9.9(8.5-11)$ & $9.2(8-10.5)$ & $\neq$ & $\begin{array}{l}5.5(4.5-6.5)^{*} \\
4.3(3-5.5)^{* *}\end{array}$ & $\begin{array}{l}3.1(2.5-5)^{*} \\
3.1(2-3.5)^{* *}\end{array}$ & $\begin{array}{l}7-9^{*} \\
5-6^{* *}\end{array}$ & $\mathrm{P}$ \\
\hline $\begin{array}{l}\text { M. inaequus Kent and } \\
\text { Hoffman, } 1984\end{array}$ & Eigemannia virescens & brain & Brazil & $19.8(15.6-22)$ & $8.6(7.8-9.3)$ & $\neq$ & \multirow{3}{*}{$\begin{array}{l}11.8(9.4-13)^{*} \\
4.8(3.9-5.5)^{* *} \\
2.7-3.6^{*} \\
1.8^{* *} \\
4.3(3.9-4.6)^{*} \\
2(1.4-2.1)^{* *}\end{array}$} & $\begin{array}{l}3.6(3.1-3.9)^{*} \\
/ * *\end{array}$ & l & $\mathrm{P}$ \\
\hline M. indicum Tripathi, 1952 & Cirrhina mrigala & $\begin{array}{l}\text { muscles, liver, } \\
\text { intestinal wall }\end{array}$ & India & $9.5-10.8$ & $7.5-8.5$ & $\neq$ & & $\begin{array}{l}1.8^{*} \\
1.0^{* *}\end{array}$ & l & A \\
\hline M. koli Lalitha Kumari, 1969 & Enteromius kolus & fins & India & $8.4(7.1-9.6)$ & $6.0(5.0-6.4)$ & $\neq$ & & $\begin{array}{l}2.8(2.1-3.1)^{*} \\
1.2(0.7-1.4)^{* *}\end{array}$ & l & A \\
\hline M. labeoi Boungou et al., 2006 & Labeo coubie & between fin rays & $\begin{array}{l}\text { Burkina } \\
\text { Faso }\end{array}$ & $16.4(16.0-17.0)$ & $10.3(10.0-12.0)$ & $\neq$ & $\begin{array}{l}8.3(7.0-9.0)^{*} \\
6.5(5.0-7.0)^{* *}\end{array}$ & $\begin{array}{l}1.5(1.6-2.0)^{*} \\
0.4(0.3-0.5)^{* *}\end{array}$ & l & A \\
\hline $\begin{array}{l}\text { M. nchoutnounensis Nchoutpouen } \\
\text { and Fomena, } 2011\end{array}$ & Labeo parvus & $\begin{array}{l}\text { gills, scales, liver, fins, } \\
\text { spleen, kidney, eyes }\end{array}$ & Cameroon & $11.8(11.0-13.0)$ & $9.2(8.5-10.0)$ & $\neq$ & $\begin{array}{l}6.0(5.0-7.0)^{*} \\
2.9(2.2-3.5)^{* *}\end{array}$ & $\begin{array}{l}4.0(3.5-4.0)^{*} \\
1.6(1.2-2.0)^{* *}\end{array}$ & $\begin{array}{l}6-9 * \\
3-4^{* *}\end{array}$ & $\mathrm{P}$ \\
\hline M. oloi Fomena and Bouix, 1994 & $\begin{array}{l}\text { Enteromius aspilus } \\
\text { E. camptacanthus } \\
\text { E. guirali } \\
\text { E. martorelli }\end{array}$ & $\begin{array}{l}\text { gill arch epithelium, } \\
\text { gullet, kidneys }\end{array}$ & Cameroon & $9.3(6.3-11.5)$ & $7.2(5.1-9.4)$ & $\neq$ & $\begin{array}{l}5.7(4.0-7.0)^{*} \\
3.9(2.2-5)^{* *}\end{array}$ & $\begin{array}{l}3.1(1.8-4.0)^{*} \\
2(1.5-2.5)^{* *}\end{array}$ & $\begin{array}{l}4-5 * \\
3 * *\end{array}$ & $\mathbf{A}$ \\
\hline M. oloi (Present study) & E. martorelli & $\begin{array}{l}\text { muscle, kidneys, spleen, } \\
\text { gonads }\end{array}$ & Cameroon & $10.2(9-11)$ & $8.2(7.8-9)$ & $\neq$ & $\begin{array}{l}6.03(5-7.2)^{*} \\
4.39(3.5-5.1)^{* *}\end{array}$ & $\begin{array}{l}3.19(2.8-3.9) * \\
2.27(2-2.7)^{* * *}\end{array}$ & $\begin{array}{l}6-7^{*} \\
4-5^{* *}\end{array}$ & $\mathbf{A}$ \\
\hline M. rohitae Haldar et al., 1983 & Labeo rohita & scales & India & $10.6(9.9-12.1)$ & $9(8.8-9.9)$ & $=$ & 6.6 & 3.3 & $5-6$ & A \\
\hline M. saranae Gupta and Khera, 1990 & $\begin{array}{l}\text { Systomus sarana } \\
\text { Puntius sarana } \\
\text { Labeo calbasu }\end{array}$ & gills & India & $7.7(6.0-9.0)$ & $6.2(6.0-7.0)$ & $\neq$ & $\begin{array}{l}4.2(4.0-5.0)^{*} \\
2.9(1.5-3.0)^{* *}\end{array}$ & $\begin{array}{l}3.0(2.5-4.0)^{*} \\
1.3(1.0-2.0)^{* *}\end{array}$ & l & A \\
\hline
\end{tabular}

The arithmetic means of the measured variables are followed in brackets by the minimum and maximum values.



filament; ICA : intercapsular appendice (A : absent ; P : present) ; * : Relative to the large polar capsule; ** : Relative to the small polar capsule;

I: No data available. 
G. B. LEKEUFACK FOLEFACK et al. / Int. J. Biol. Chem. Sci. 13(3): 1705-1719, 2019

Table 3: Comparison chart between Myxobolus njinei Fomena, Birgi and Bouix, 1985 and close related described species (measurements in micrometers).

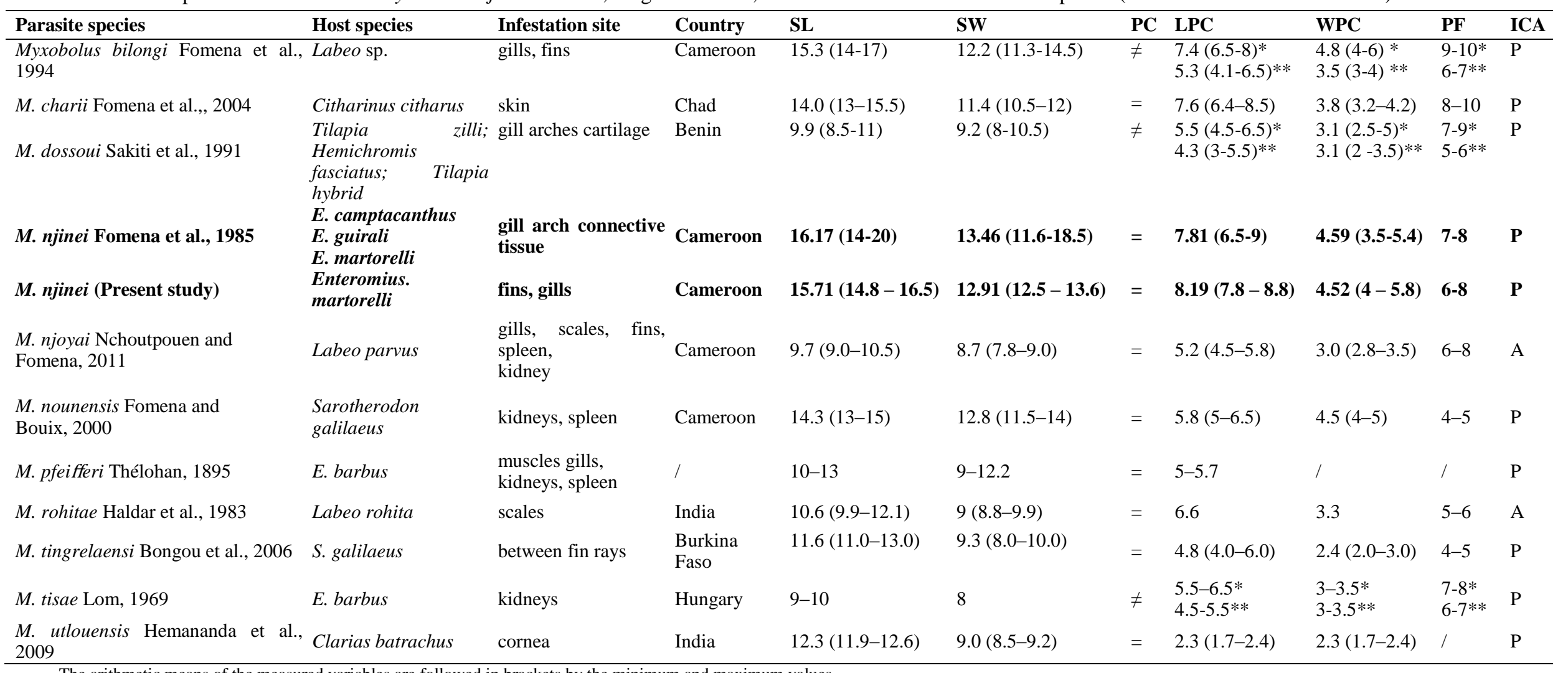

The arithmetic means of the measured variables are followed in brackets by the minimum and maximum values

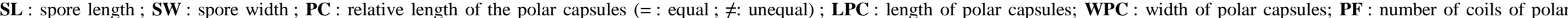

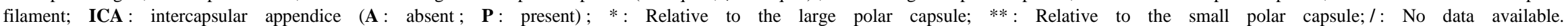



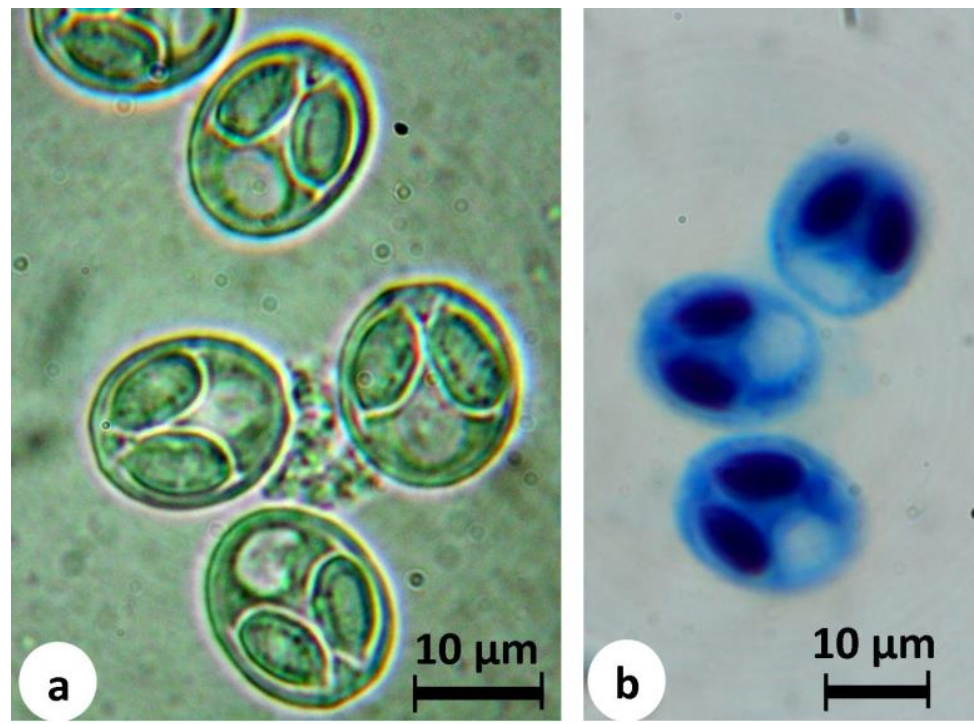

Figure 4 (a,b): Optical photomicrographs of myxospores of Myxobolus njinei released from a mature plasmodium from the fin of Enteromius martorelli. a. Fresh myxospores; b. Coloured myxospores.

\section{Alestes dentex (Alestidae), Labeo parvus (Cyprinidae), Oreochromis niloticus} (Cichlidae) and S. galilaeus in Chad (AbakarOusman, 2006; Kostoingue and Toguebaye, 1994); Enteromius poechii (Cyprinidae) in Botswana (Reed et al., 2002); L. parvus in Cameroon (Nchoutpouen, 2015). Thus, M. nyongana is an ubiquitous parasite with a broad specificity of euryxenous type (Palm and Caira, 2008). In E. martorelli, M. nyongana forms numerous cysts between secondary gill lamellae. The gill is a complex organ. Beside the cartilaginous, sometimes osseous, solid gill arch, it contains gill filaments consisting of cartilaginous, fibrous and epithelial elements. It constitutes the hemibranchia, as well as gill lamellae (respiratory plates) that are separated from the surroundings by an epithelial and an endothelial layer (Molnár, 2002a). According to Molnár (2002a), the location of $M$. nyongana on $E$. martorelli is of the interlamellar type. This parasite could give rise to bulky cysts, which can affect the gill functions and drastically reduce the respiratory surface. The location of plasmodia in interlamellar site was revealed to be associated with hypertrophy and inflammation. Lekeufack Folefack et al.
(2019), believe that rupture of cysts can lead to haemorrhages, and sometimes may result in considerable loss of blood. In case of severe infection, hypertrophy of the basal epithelial can lead to increase in mucus production. Furthermore, cellular changes may lead to the fusion of adjoining secondary gill lamellae as reported by Kaur and Katoch (2014). Thus, the death of the fish host could occur following invasion of the gills by cyst of $M$. nyongana.

Myxobolus oloi was described on the gill arch, pericardium and esophagus of many cyprinids fish of the genus Enteromius (E. aspilus, E. camptacanthus, E. guirali and E. martorelli) in Cameroon (Fomena and Bouix, 1994). In the present study, M. oloi was found in the muscle, kidneys, spleen and gonads of E. martorelli, one of its original host species. This parasite therefore has a narrow specificity of the mesostenoxenous type (Palm and Caira, 2008). In the literature, some species of the genus Myxobolus were reported in the skeletal muscle of fish hosts (Molnár and Székely, 2014); however, this is the first record on E. martorelli that may present important consequence to fish farming. Skeletal muscle is the main constituent of the fish body. In addition to muscle cells, the 
musculature contains blood vessels, nerves and connective tissue as well as cartilaginous and bony elements (Roberts and Ellis, 2012). Analysis of the histological sections shows that, the mechanical pressure exerted by the plasmodia of $M$. oloi on the surrounding muscle fibers is not accompanied by inflammatory response. This finding corroborates the information revealed by Molnár and Eszterbauer (2015) on the absence of inflammation and the reduction of cells around plasmodia of Myxobolus spp. in Cyprinids fish. Myxosporidia responsible for myoliquefactive conditions in fish presumably excrete histolytic enzymes which diffuse into the surrounding muscle (Yokoyama and Masuda, 2001). Yokoyama and Masuda (2001) suggested that the histolytic enzymes could be excreted continuously but removed by vascular perfusion in the live fish, or only released once the spores or plasmodia die. It is thus also plausible that myxosporidia species initiates excretion of histiolytic enzymes in response to death of its hosts, in order to facilitate spore release from the infection sites. Since the presence of plasmodia of M. oloi in E. martorelli can cause mechanical compression in its muscles, this parasite species has a significant economic impact because of possible postmortem myoliquefaction. This muscle lysis effect comes from the action of proteases, thereby leaving the muscle of the fish host softened (Andranda et al., 2005). Given the evidence that consumption of fish infected with myxosporidia can cause allergy symptoms or food poisoning (Kawai et al., 2012), the presence of a high number of $M$. oloi cysts in E. martorelli muscle can compromising the acceptance of the fish among consumers.

The fin is one of the most preferred sites for the development of species of myxosporidia parasitizing fish (Molnár, 2002b). Myxobolus njinei, originally described in the gill arch of fish species of the genus Enteromius (E. camptacanthus, E. guirali and E. martorelli), was found on the fins and gill arch of E. martorelli (one of its original host). Therefore, it has a narrow specificity of the mesostenoxenous type (Palm and Caira, 2008). The fin is an organ of rather simple structure, composed of epithelial, connective tissue endothelial elements and the chondrifying collagenous substance of the finrays (Roberts and Ellis, 2012). According to Molnár (2002b), the presence of myxosporidia cysts between the finrays would not result in inflammatory response of the host. Whereas in the finrays, they can compress blood vessels and peripheral nerves near the cartilage but would not lead to morphological modification of its substance. Similarly, plasmodia contiguous to the finrays can cause deformation of the cartilage if they penetrate it. Plasmodia of M. njinei most often develop inside the cartilaginous finray, do not substantially deform the cartilaginous structure but extend from it, through the lateral hiatus, to the connective tissue between the finrays. The formation of plasmodia exceeding in size the diameter of the finrays is facilitated by the lateral bulge and also by the fact that the plasmodia typically colonise the region connecting the longitudinal segments of the finrays (intersegmental joints) (Molnár, 2002b). Histological findings indicate that $M$. njinei causes only minor local changes on the fins of E. martorelli. According to Molnár (2002b), the pathological importance of changes caused by myxosporidia greatly depends on the intensity of parasite colonisation, the size of plasmodia and the number of spores, but the type of the attacked organ is also important. Parasites colonising vital organs such as the gills or the brain have much higher pathogenicity (Molnár and Eszterbauer, 2015). Fish fin being organ of lesser vital importance, the damages caused on E. martorelli by M. njinei can result only in overall weakness and slow swimming movements that can finally make this fish host susceptible to predators. Furthermore, if the plasmodia of $M$. njinei are not directly lethal to E. martorelli, they inevitably affect the anatomy and physiology of the affected fins. Moreover, rupture of cysts of $M$. njinei on fins can create lesions which constitute penetration 
sites for secondary fish pathogens such as bacteria and fungi.

\section{Conclusion}

This study shows that, infection by Myxobolus spp. studied apparently did not significantly affect the general health of the fish, the histopathological changes shows that a high parasite load could compromise the function of affected organs. However, the histopathological analysis only addressed the wild host specimens and we do not know the impact that infection by studied parasite species may have on farmed specimens, especially in intensive farming. Thus, the presence and dispersion of these parasites species needs to be monitored closely by fish farmers. Because of the uncertain taxonomy of some species assigned to the genus Myxobolus, the taxonomic position of these parasites requires further study. Although many studies on fish myxosporiosis are available in Cameroon, the life cycle of Myxozoan species remain unknown. Further study is necessary to clarify their life cycle.

\section{COMPETING INTERESTS}

The authors declare that they have no competing interests

\section{AUTHORS' CONTRIBUTIONS}

GBLF and AF designed the research protocol; GBLF, AETT, BFD, LMN participated in field and laboratory work; all the authors participated in the data analysis and the manuscript writing.

\section{ACKNOWLEDGEMENTS}

The authors are thankful to the Faculty of Science, University of Yaounde I, Yaounde-Cameroon, for providing all the facilities to complete this work.

\section{REFERENCES}

Abakar-Ousman. 2006. Myxosporidia (Myxozoa: Myxosporea) parasites of Chad freshwater fish: fauna and biology of the parasites species of Oreochromis niloticus (Linne, 1758) and Sarotherodon galilaeus (Linné, 1758)
(Cichlidae). PhD thesis, University of Yaounde I, Yaounde, p. 163.

Andranda CDG, Tortelly R, Pereira Nogueira P, Leal Andrade C, De Lima FC. 2005. Kudoa Meglitsch, 1947 (Myxozoa: Multivalvulida) infection in somatic muscles of cutless fish Trichiurus lepturus (Teleostei: Trichiuridae). Parasitolo. Latinoam., 60(3-4): 150-153. DOI: http://dx.doi.org/10.4067/S071777122005000200008

Eiras JC, Molnár K, Lu YS. 2005. Synopsis of the species of Myxobolus Bütschli, 1882 (Myxozoa: Myxosporea: Myxobolidae). Syst. Parasitol., 61: 1-46. DOI: https://doi.org/10.1007/s11230-0046343-9

Eiras JC, Zhang J, Molnár K. 2014. Synopsis of the species of Myxobolus Bütschli, 1882 (Myxozoa: Myxosporea, Myxobolidae) described between 2005 and 2013. Syst. Parasitol., 88: 11-36. DOI: https://doi.org/10.1007/s11230014-9484-5

Fiala I, Bartošová-Sojková P, Whipps CM. 2015. Classification and phylogenetics of Myxozoa. In Myxozoan Evolution, Ecology and Development, Okamura B, Gruhl A, Bartholomew JL (ed). Springer; 85-110.

Fomena A, Bouix G. 1994. New Myxosporidia species (Myxozoa) from freshwater Teleosts in Southern Cameroon (central Africa). J. Afr. Zool. 108: 481- 491.

Fomena A, Marques A, Birgi E. 1985. Contribution to the study of Myxosporidians of fresh water fishes in Cameroon. II. New species of Myxobolus Butschli, 1882. Bull. I.F.A.N.T. Ser. A, 167-192.

Hayes MM, Armbruster JW. 2017. The Taxonomy and Relationships of the African Small Barbs (Cypriniformes: Cyprinidae). Copeia, 105: 348-362. DOI: https://doi.org/10.1643/CI-15-348

Kaur H, Katoch A. 2014. Gill disease caused by Thelohanellus bifurcata Basu and Haldar, 1999 a pathogenic myxozoan 
parasite in cultured Indian carp, Labeo rohita (Hamilton, 1822) in Punjab, India. India J Anim Health. Prod, 2(2): 19-24. DOI:

http://dx.doi.org/10.14737/journal.jahp/2 014/2.2.19.24

Kawai T, Sekizuka T, Yahata Y, Kuroda M, Kumeda Y, Iijima Y, Kamata Y, SugitaKonishi Y, Ohnishi T. 2012. Identification of Kudoa septempunctata as the causative agent of novel food poisoning outbreaks in Japan by consumption of Paralichthys olivaceus in raw fish. Clin. Infect. Dis., 54(8): 1046-1052.

DOI:https://doi.org/10.1093/cid/cir1040

Kostoingue B, Toguebaye BS. 1994. Le genre Myxobolus (Myxozoa: Myxosporea) chez les poissons d'eau douce du Tchad avec la description de trois nouvelles especes. Bull. Inst. Fond. Afr. Noire, 47: 63-71.

Kostoïngue B. 1997. Contribution à l'étude des Myxosporidies (Myxozoa) parasites des poissons d'eau d'eau du Tchad: Taxonomie, Ultrastructure and Biologie (Thèse de Doctorat de 3ème cycle). Université Cheikh Anta Diop de Dakar, Dakar, p. 138.

Lekeufack Folefack GB, Fomena A. 2013. Structure et dynamique des infracommunautés de Myxosporidies parasites de Ctenopoma petherici Günther, 1864 (Anabantidae), Clarias pachynema Boulenger, 1903 (Clariidae) et Hepsetus odoe (Bloch, 1794) (Hepsetidae) dans la rivière Sangé au Cameroun. Int. J. Biol. Chem. Sci., 7(6): 2301- 2316.2 DOI: http://dx.doi.org/10.4314/ijbcs.v7i6.11

Lekeufack Folefack GB, Defoueng NAS, Fomena A. 2017. Three New Species of Myxobolus (Myxosporea: Myxobolidae), Parasites of Barbus callipterus Boulenger, 1907 in Cameroon. Asian J. Biol. Sci., 10(3): 110-120. DOI: https://doi.org/10.3923/ajbs.2017.110.12 0
Lekeufack Folefack GB, Abdel-Baki AAS, Onana Ateba NO, Fomena A, Mansour L. 2019. Morphological and molecular characterization of Myxobolus dibombensis sp. n. (Myxozoa: Myxobolidae), a parasite of the African carp Labeobarbus batesii (Teleostei: Cyprinidae) from Dibombe River, Cameroon. Parasitol. Res., 118(3): 763771.

DOI:

https://doi.org/10.1007/s00436-01906209-w

Lipato I, Kapute F. 2017. Nutritional quality of Barbus paludinosus (matemba) smoked using traditional and improved smoking methods. Int. Food Res. J., 24(4): 1507.

Lom J, Arthur JR. 1989. A guideline for the preparation of species descriptions in Myxosporea. J. Fish Dis., 12(2): 151156.

DOI: https://doi.org/10.1111/j.13652761.1989.tb00287.x

Lom J, Dykova I. 2006. Myxozoan genera: definition and notes on taxonomy, lifecycle terminology and pathogenic species. Folia Parasitol., 53(1): 1-36. https://doi.org/10.14411/fp.2006.001

Molnár K. 2002a. Site preference of fish myxosporeans in the gill. Dis. Aquat. Organ., 48(3): 197-207. DOI: https://doi.org/10.3354/dao048197

Molnár K. 2002b. Site preference of myxosporean spp. on the fins of some Hungarian fish species. Dis. Aquat. Organ., 52(2): 123-128. DOI: https://doi.org/10.3354/dao052123

Molnár K. 2007. Site preference of myxozoans in the kidneys of Hungarian fishes. Dis. Aquat. Organ., 78(1): 45-53. DOI: https://doi.org/10.3354/dao01827

Molnár K, Eszterbauer E. 2015. Specificity of infection sites in vertebrate hosts. In Myxozoan Evolution, Ecology and Development, Okamura B, Gruhl A, Bartholomew JL (ed). Springer; 295313.

Molnár K, Székely C. 2014. Tissue preference of some myxobolids (Myxozoa: 
Myxosporea) from the musculature of European freshwater fishes. Dis. Aquat. Organ., 107(3): 191-198. DOI: https://doi.org/10.3354/dao02688

Nchoutpouen E. 2015. Myxosporidia (Myxozoa: Myxosporea) parasites of some teleosts of the Noun Basin (West Region, Cameroon): taxonomy and biology of species parasitizing Oreochromis niloticus Linneaus, 1758 and Labeo parvus Boulenger, 1902. PhD thesis, University of Yaounde I, Yaounde, p. 202.

Palm HW, Caira JN. 2008. Host specificity of adult versus larval cestodes of the elasmobranch tapeworm order Trypanorhyncha. Int. J. Parasitol., 38(34): $\quad 381-388 . \quad$ DOI: https://doi.org/10.1016/j.ijpara.2007.08.0 11

Reed CC, Basson L, Van As LL. 2002. Myxobolus species (Myxozoa), parasites of fishes in the Okavango River and Delta, Botswana, including descriptions of two new species. Folia parasitol., 49(2): 81-88.

Roberts RJ, Ellis AE. 2012. The Anatomy and Physiology of Teleosts. In Fish Pathology, Roberts RJ (ed.). WileyBlackwell: Oxford; 17 - 61.

Sakiti G. 1997. Myxosporidies et Microsporidies de Poissons du Sud Bénin : Faunistique, Ultrastructure, Biologie. Thèse de Doctorat d'Etat, Université national du Bénin, AbomeyCalavi, 296 p.

Stiassny ML, Teugels GG, Hopkins CD, Paugy D. 2007. Poissons d'Eaux Douces et Saumâtres de la Basse Guinée, Ouest de l'Afrique Centrale. Collection Faune et Flore Tropicales, IRD: Paris, France.

Yokoyama H, Masuda K. 2001. Kudoa sp. (Myxozoa) causing a post-mortem myoliquefaction of North Pacific octopus Paroctopus dofleini (Cephalopoda: Octopodidae). Bull. Eur. Assoc. Fish. Pathol., 21: 266-268. 